\title{
The restorations of ancient monuments of Cyprus from the establishment of the Department of Antiquities of Cyprus in 1935 until 2005
}

\author{
E. Limbouri \\ Independent scholar, Cyprus
}

\begin{abstract}
The subject of this presentation is the restorations of the ancient monuments of Cyprus from the establishment of the Department of Antiquities in 1935 until the present day (2005), which was the theme of my dissertation.

For a better understanding of the restorations, the time lap between 1935 and 2005 has been divided into four periods. The four periods have been specified according to the date-landmarks for the history of the island in general and for the operation of the Department of Antiquities in particular.

The first period is a short chronicle of the restoration works in Cyprus until the establishment of the Department of Antiquities. Emphasis is being given to the last years of the $19^{\text {th }}$ and the first years of the $20^{\text {th }}$ century when the theories of restoration that were spread out in the United Kingdom affected the island which was, at that time, a British colony.

The second period covers the interval 1935-1960, that is from the establishment of the Department of Antiquities by the Colonial Government until 1960 when Cyprus became independent. The third period covers the period 1960-1974, from the Independence until the Turkish invasion of 1974 and the fourth period extends from 1974 until 2005. In each period, we examine to see which were the monuments that were restored, if there were any tendencies in these restorations, and to what extent were the restorations on the monuments of Cyprus related to the principles and theories of restoration that existed in the same period in the rest of Europe as well as to those followed today.

Keywords: Cyprus, restoration, monuments, Cyprus Department of Antiquities.
\end{abstract}




\section{Introduction}

The lack of any publication in regards to the restorations of monuments of Cyprus was the principal motivation for this dissertation, which examines the evolution of restorations from the establishment of the Department of Antiquities of Cyprus in 1935 until 2005. The aim was the systematic study and the recording of the significant restoration works carried out on the ancient monuments of Cyprus in order to:

a) establish the chronicle of the restorations of ancient monuments from the time the Department of Antiquities was founded until the present day

b) reassess errors or omissions that had occurred during this period

c) assist conservators / restorers carrying out future restorations by providing them with important information regarding the monuments

d) evaluate these restorations in regards to the theories and principles of restoration that existed at the same period in the rest of Europe as well as those followed today

e) make known the people or entities that contributed to the protection of the ancient monuments of Cyprus.

\section{The restorations of monuments until the establishment of the Department of Antiquities in 1935}

\subsection{Early Christian period (46-649AD)}

The first information in relation to how the antiquities of Cyprus were treated in the course of time goes back in the Early Christian Period. The first Christians in their effort to establish the new religion were destroying classical antiquities without acknowledging to them any artistic or historical values. Particularly for the monuments, the tendencies that were followed were two. The main one wanted the monuments of antiquity being destroyed and their materials used for the erection of the new Christian buildings. The second one, that appeared in a smaller extent though, wanted the buildings of classical antiquity converted according to the needs of their new function. An example of this practice is the Gymnasium of Salamina that was converted into therme (baths) in the reconstruction of the city after the severe earthquakes (first half of the $4^{\text {th }}$ century AD) by Emperor Constantio II (337-361AD) (Karageorghis [1]).

\subsection{Byzantine period (649-1191 AD)}

In the Byzantine Period, the new religion has been well established and the destruction of the monuments of classical antiquity was therefore limited to a smaller extent than in the previous period. The works of classical antiquity were still not appreciated for their historical or aesthetical values.

During the Byzantine period, the most common phenomenon is the renovations of older buildings with continuous additions to the existing ones. 
These additions were usually in contrast to the scale and character of the existing building and in accordance to the style of the period. The practice of reusing spoils from pagan buildings remains a common trend for the Byzantine period, as well (Karadedos [2]).

\subsection{Frankish period (1192-1489)}

The Frankish period in Cyprus is a very fruitful era for the architecture of the island. Guy de Lusignan, the first King of the Lusignan dynasty who ruled Cyprus, tried to settle the island by bringing with him to Cyprus population from the Levant. He also brought along to Cyprus masons and craftsmen that would build palaces, castles and churches on his behalf (Enlart [3]). Soon, the image of the principal cities of Cyprus with the biggest gathering of western population rapidly changed due to the erection of great cathedrals as well as other public buildings. In the countryside, where there was no western population and it was only inhabited by the natives, the Byzantine element remained dominant.

\subsection{Venetian period $(1489-1570 / 71)$}

During the Venetian period, there was a turn towards military architecture since the Venetians's priority was the erection of new defence works because they were afraid of a possible Ottoman invasion. The Frankish defence system of the capital city of Cyprus, Nicosia, was found by the Italian engineers unsuitable to protect the city. The Venetians decided to build new massive defence walls with a smaller perimeter than of the Frankish. In the construction of the new walls of Nicosia, all the buildings that happened to be outside the new perimeter were demolished (Kyprianos [4]). Spoils from these buildings were used in the construction of the new walls (Fig. 1).

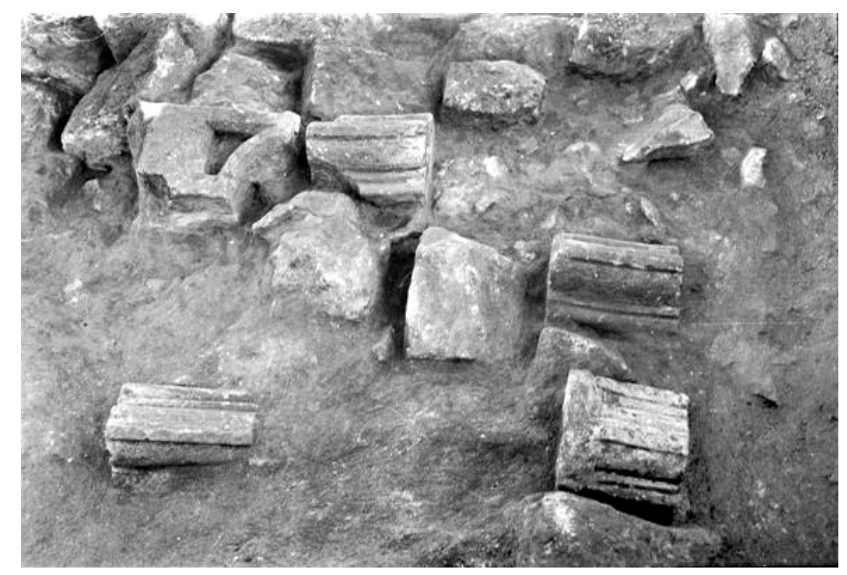

Figure 1: Spoils in second use found during the restoration of the roof of Famagusta Gate. 


\subsection{Ottoman period (1570/71-1878)}

The most common phenomenon during the Ottoman period is the transformation of the medieval cathedrals and byzantine churches into mosques. The Ottoman authorities prohibit the erection of new religious buildings and they only allow the fixing and repairing of the existing ones after obtaining a relevant permission (Theocharides [5]). During this period, the first laws in relation to the matter of antiquities were put in force.

\subsection{The years of the British occupation until the establishment of the Department of Antiquities (1878-1935)}

In the years of the British occupation, the practice of using monuments of the previous centuries for extracting stones becomes a serious threat for the monuments of Cyprus. This practice is disturbing not only the colonial government of the island, but also organizations in the United Kingdom such as the S.PA.B - the Society for the Protection of Ancient Buildings. From a letter of the Society addressed to the Chief Secretary on the 17th December 1897, we quote the following: "the Committee has from time to time had its attention called to the effect that the splendid remains of churches and palaces of the Lusignan and Venetian periods at Famagusta afford a stone quarry for Port Said" (State Archives [6]).

\subsubsection{The first restoration works of the monuments of Cyprus}

During the British occupation, the first restorations of the monuments of Cyprus are taking place. George Jeffery, the man behind those, can be considered as the forerunner of the contemporary restorations. George Jeffery (Fig. 2(a)) was an architect and curator of monuments from 1903 until his death in 1935, with the only exemption of the years 1919-1921 (Annual Report 1934 [7]).

Jeffery's name is closely linked to the island's castles and churches to the protection of which he devoted a great part of his life. That so many monuments have escaped destruction must in a large measure stand to his personal credit. Jeffery, as a true follower of the anti-restoration movement was denouncing any sort of restoration. The majority of the restoration works that he had done during this period can be regarded as conservative repairs in order to prevent the monuments from collapse.

The second great personality of the period is William Douglas Caroe (Fig. 2(b)). Caroe's contribution to the restorations of monuments of Cyprus is mainly through his writings on the subject. In Caroe texts, we find references to the "restauro filologico" that made its appearance some years before in Europe, the ideas of which were expressed by Camilo Boito. Such references are his recommendations that the new work should express itself as such, but should and can do so without being ugly in itself or out of harmony, that the use of new stone is not to be wholly denied but should be as reticent as possible and only in cases of necessity and that the new stone should bear a mark like the ancient mason's (Caroe [8]). For the first time in the history of restoration of Cyprus, the 


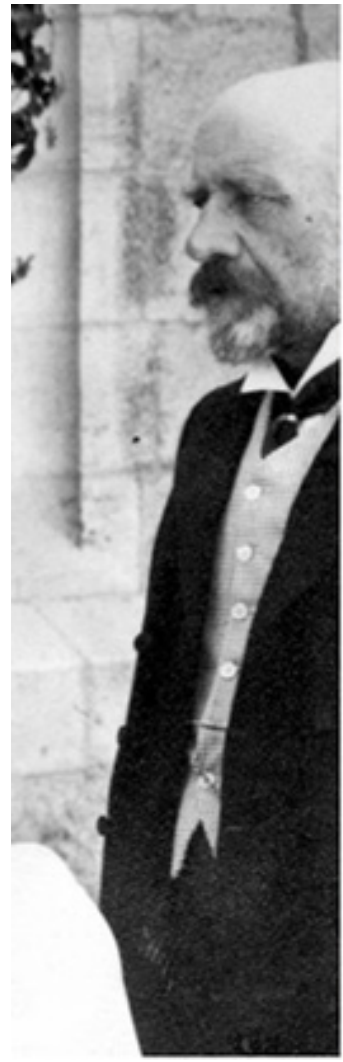

(a)

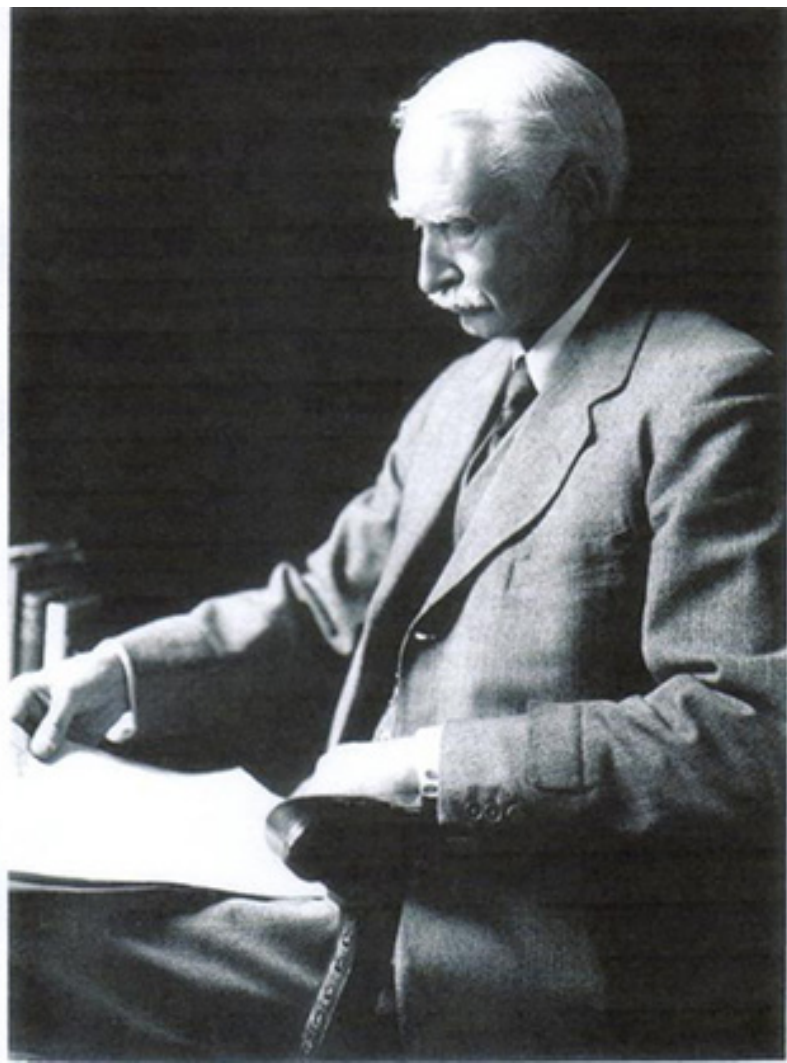

(b)

Figure 2: On the left, George Jeffery, Curator of Monuments of Cyprus (1903-1935) and on the right William Douglas Caroe.

theories of restoration that are prevailing in the rest of Europe are spread out at the same time in Cyprus.

\section{The restorations of monuments from the establishment of the Department of Antiquities in 1935 by the colonial government until the independence of Cyprus in 1960}

In the twenty five years from the establishment of the Department of Antiquities in 1935 until the Independence of the island in 1960, the British colonists focused their attention on the mediaeval monuments of Cyprus because they saw in them the continuation of their own western civilization.

The British seem to adopt the separation of these monuments into "living" and "dead" monuments, a terminology first introduced by the Belgian Louis Cloquet at the Madrid Congress of Architects in 1904 (Karadedos [9]). 
According to this distinction, "dead monuments" are considered those that have been abandoned and do not have any use while "living" those that still function according to their first use. The Congress resolved that only in the case of the living monuments was restoration to be allowed. The dead monuments were only to be carefully preserved (Brown [10]).

The British colonists fully adopt this resolution. In the case of the dead monuments, there is a denial for reconstruction of the parts that have been destroyed. Most of the interventions to these monuments were usually fixative works in order to prevent the rest of the monument from collapse. The most characteristic examples in this category are the church of St. George of the Greeks (Fig. 3) and the church of St. George of Latins, both situated in Famagusta. In cases of living monuments such as the church of St. Peter and Paul in Famagusta that was turned into a museum, the British proceeded with the reconstruction of the tracery of the windows (Figs. 4(a) and (b)) and used cement for waterproofing its roof. The stylistic restorations during this period were very limited.

The surrounding area of the monuments gained much importance during this period. The existence of a law that deals with this matter verifies this fact. Specifically, Article 11 of the Cyprus Law of Antiquities of 1935, adopting the provisions of Article 7 of the Charter of Athens for respect to the character of the

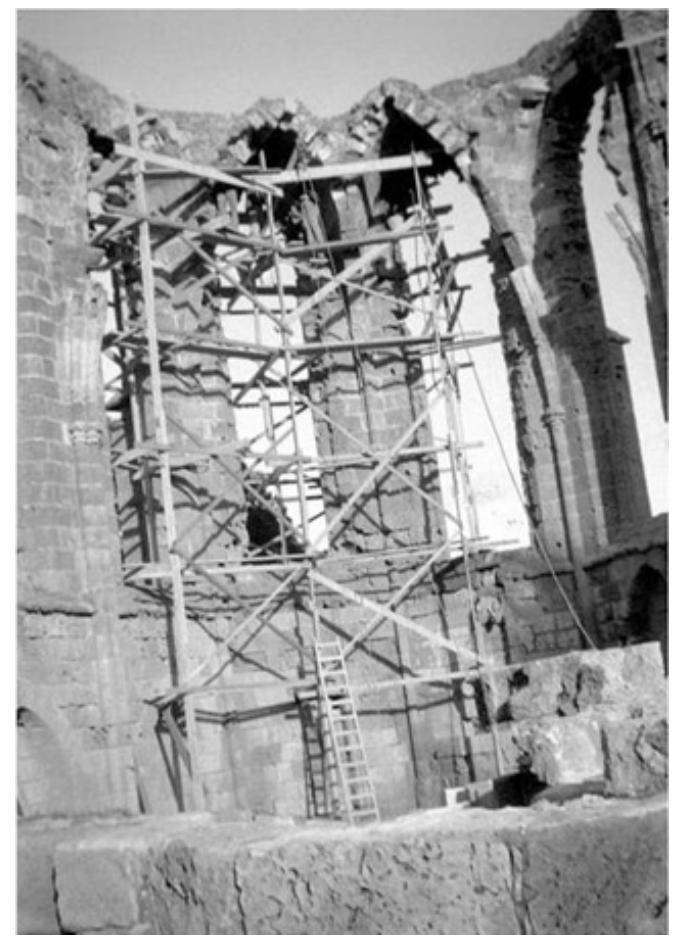

Figure 3: $\quad$ St. George the Latins in Famagusta in 1937. 


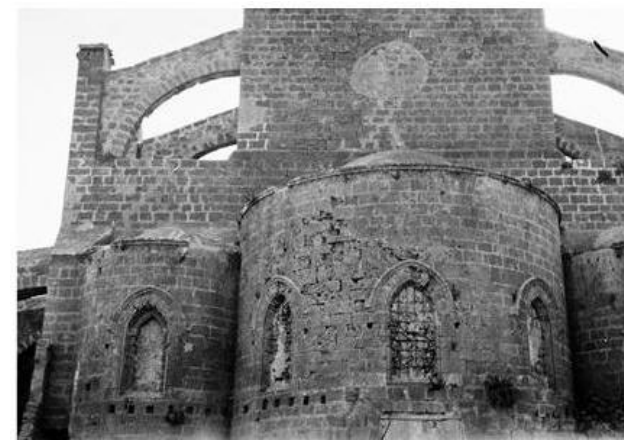

(a)

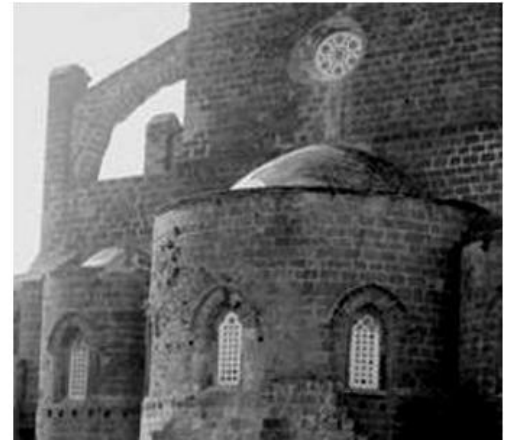

(b)

Figure 4: Church of St. Peter and Paul in Famagusta before (a) and after the restoration works of 1937 (b).

area in the vicinity of the monuments, states the following: "the Governor, with a view to ensuring that buildings in the neighbourhood of an ancient monument shall as regards height and style of architecture be in keeping with the character and style of such monument and that the amenities thereof may be preserved, may by notice to be published in the Gazette order that, within such area as may be specified in such notice no building shall be erected, reconstructed or repaired and no tree shall be felled save in accordance with the terms of a permit in writing from the Commissioner previously obtained".

The restoration works on Byzantine monuments begun in the 1950s with the painted churches in the mountain area of Troodos. This type of church is a very unique type of building which can be found only in Cyprus. Eleven of these churches are inscribed in UNESCO's World Heritage List of Monuments. These restoration works mainly concerned reconstructions of the timber roofs, that due

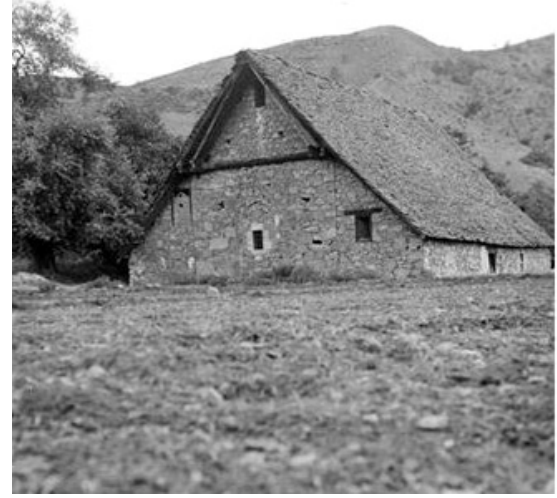

(a)

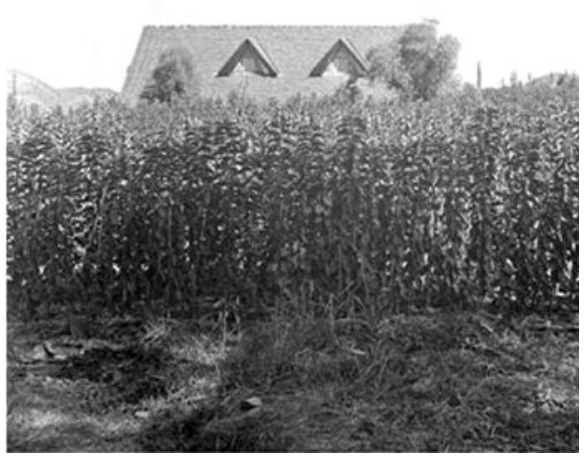

(b)

Figure 5: Panayia Podithou in Galata before and after the restoration of its roof in 1956. The triangular skylights have been removed in 1999. 
to their vulnerability many of them had suffered serious damage. During the reconstruction of the roof, many serious errors occurred in several cases, such as the introduction of new morphological characteristics (the triangular skylights in the church of Panayia Pothydou in the village of Galata) (Figs. 5(a) and (b)) or the changing of the inclination of the pitched roof for obtaining better drainage thus altering the character of the monument (Panayia Phorviotissa in Asinou) (Figs. 6(a) and (b)).

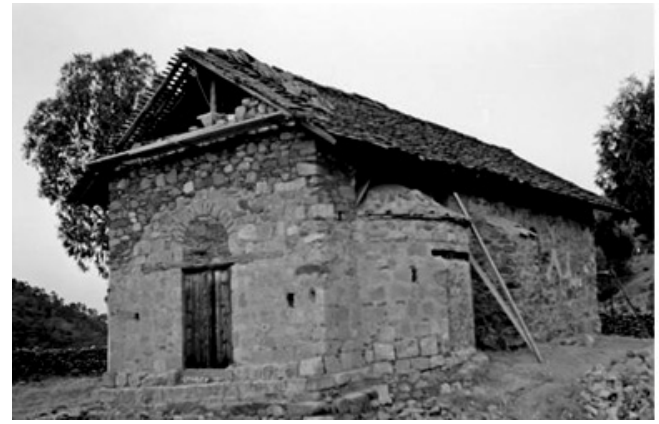

(a)

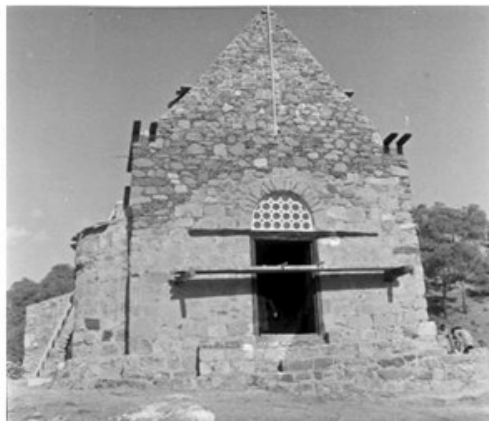

(b)

Figure 6: Panayia Phorviotissa (Asinou) in Nikitari before and during the restoration of 1959 when the inclination of its timber roof drastically changed.

\section{The restorations of monuments from the independence of the island in 1960 until the Turkish invasion of 1974}

With the takeover of the administration of the Department of Antiquities by the Cypriots, the emphasis was turned to the byzantine monuments of the island. The new administration wished to promote the monuments of Cyprus that were closely linked with the island's Greek Orthodox religion and civilization. Therefore, all the attention was then focused on the painted churches, acknowledging their uniqueness as well as the artistic value of their wall paintings.

The restoration works on the painted churches during this period (1960-1974) were characterized by a critical attitude towards previous restorations that had caused the alteration of the monuments. After reassessing them, the Department of Antiquities proceeded to take corrective measures in order to remove recent interventions that were altering the character of the monument. Such example is the case of Panayia Chrysokourdaliotissa in Kourdali (Figs. 7(a) and (b)). Panayia Chrysokourdaliotissa is the only three-aisled painted church in Cyprus where the aisles are divided by rows of wooden posts. The church is made out of local stones and mud and the thickness of the walls is $55 \mathrm{~cm}$. The plan of the church is an irregular rectangle with the north and middle aisle being $16.90 \mathrm{~m}$ lengthwise while the south one, $15.40 \mathrm{~m}$. The width of the church is $8.25 \mathrm{~m}$. 


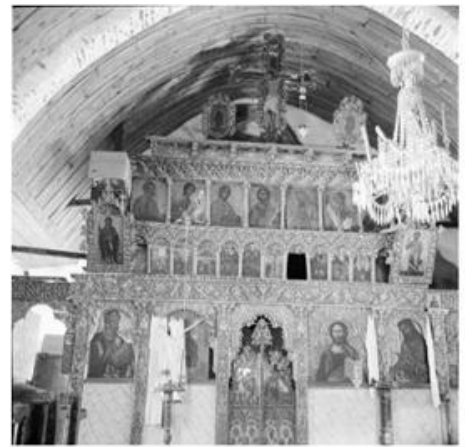

(a)

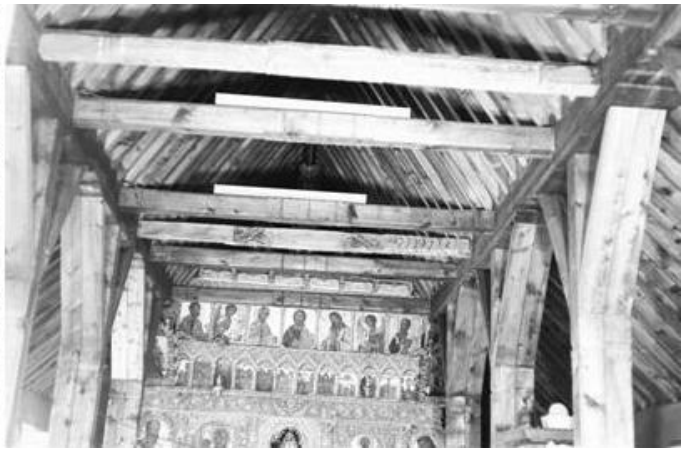

(b)

Figure 7: Panayia Chrysokourdaliotissa in Kourdali before and after the restoration of its timber roof in 1966.

In the category of the other types of Byzantine buildings asides the painted churches, in contrast to the provision of the Charter of Venice that was signed in 1964 that restoration stops were speculations begin, the tendency was the reconstruction that could concern some of the destroyed parts of the monument, as in the case of Panayia Kriniotissa in Vasilia (Figs. 8(a) and (b)) or the complete reconstruction of the monument, such as the case of Panayia Chrysolakourna in Steni (Figs. 9(a) and (b)). Figs. 8(a) and (b) show Panayia Kriniotissa, a small church made out of local stones. The church belongs to the compressed cross in square type with a dome with a semi-circular apse at the east and a narthex at the west. Its internal dimensions are $3.90 \mathrm{~m} \times 6.90 \mathrm{~m}$ without the apse. The church of Panayia Chrysolakourna (Figs. 9(a) and (b)) was most probably built in the 12th century, and it was transformed into a three-aisled basilica at the end of the 15th or beginning of the 16th century. Although, much in ruins it was decided in 1974 to restore the church in the form that it presumably had in the 16th century.

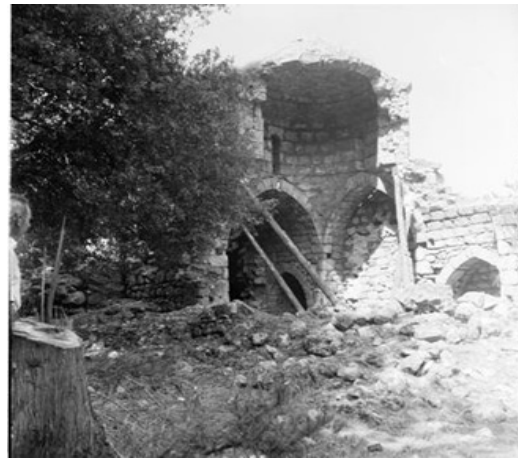

(a)

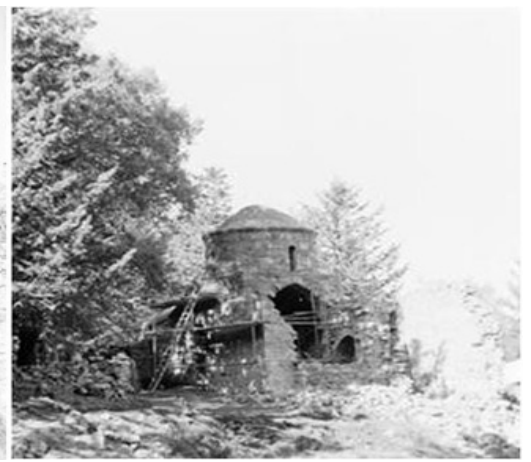

(b)

Figure 8: Panayia Kriniotissa in Vasilia. Before and after the restoration of its dome. 


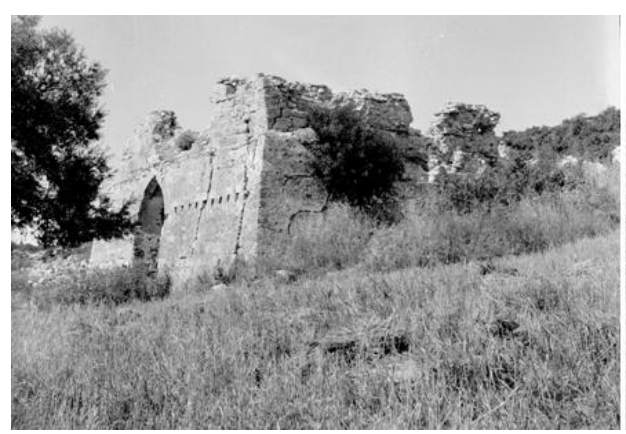

(a)

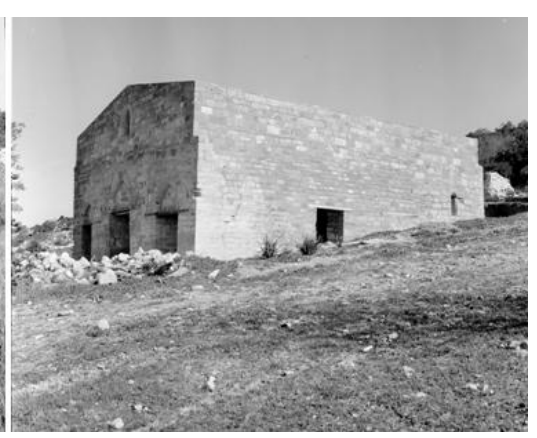

(b)

Figure 9: Panayia Chrysolakourna in Steni before and after reconstruction.

The number of restoration works on mediaeval monuments during 1969 and 1974 is very limited, since the majority of the mediaeval monuments that were situated in Nicosia and Famagusta due to the Turkish Cypriot uprising of 1964 and the creation of ghettos were inaccessible. An important restoration work of a mediaeval monument that a special reference should be made, is the structural restoration of the Cathedral of St. Sophia in Nicosia in 1968 under the technical direction of UNESCO experts Professor P. Gazzola and Dr. C. Musso (Fig. 10). The thirteenth century cathedral which is constructed by coarse-grained limestone from Kyrenia consisted of a nave of four bays with a porch at the west end extending over the whole of the facade, a simple transept whose salient arms are of the same height as the aisles, a two-storeyed chapel probably used as a treasury, and a seven-sided polygonal choir and ambulatory without chapels. Later on, two chapels were built protruding from the southern side-aisle. Shortly afterwards, when the porch was built, two towers were constructed but it seems that they were never finished. The towers have been turned into minarets when the cathedral was turned into a mosque. Its interior was also white-washed.

This is the first time that a reference is made, in the report for the restoration of St. Sophia, to the Charter of Venice (Musso [11]). Another important thing in relation to this restoration is that for the first time an appropriate mortar was used for the consolidation of the masonry instead of cement mortar that was commonly used in all the restorations of this period.

During the years 1960-1974, the interest of the Department of Antiquities for the monuments of the recent past begins to arise. However, restoration works on this category of monuments will not begin until the next period, and in particular after the 1980s.

Concluding this period, a special reference should be made to the reconstruction of the ancient theatres that excavations brought to light with the intention for those to be used for cultural and other events. The first theatre to be restored was the ancient theatre of Salamina; then followed the ancient theatre of Kourio and Soloi and by the end of this period, the restoration of the Roman Odeon of Paphos began. The central section of the cavea of Kourion Theatre is cut in the native rock (Figs. 11(a) and (b)). The rock itself is the uneven limestone which prevails in the region; hard in some places and soft in others. 


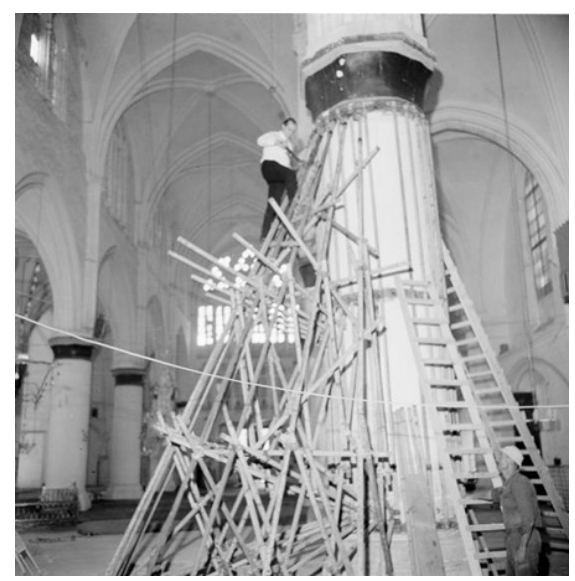

Figure 10: The cathedral church of St. Sophia in Nicosia during restoration.

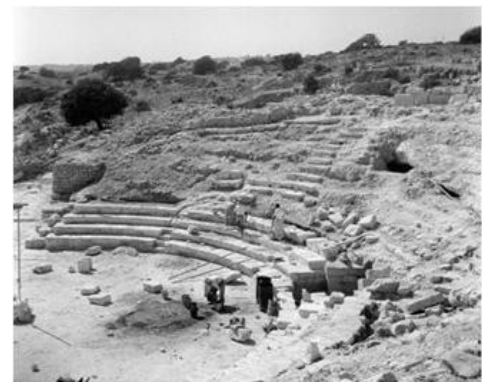

(a)

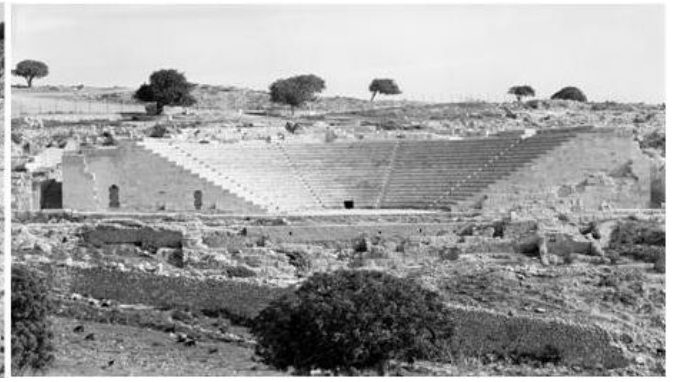

(b)

Figure 11: The ancient theatre of Kourion before and after reconstruction.

\section{The restorations of monuments from the Turkish invasion of 1974 until the present day (2005)}

The Turkish invasion of 1974 and the continuous occupation until now of $37 \%$ of the territory of Cyprus has brought radical changes to the operation of the Department mainly because the monuments in the occupied areas remain inaccessible and vulnerable to several destructions. Therefore, the attention has now shifted to the monuments in the non-occupied area on the south.

During this period the number of restoration works was considerably increased. Basically, this number concerns restoration works of Byzantine and monuments of the recent past, namely monuments of vernacular architecture.

Further, in the category of the Byzantine monuments the majority of the restoration works concern restorations of the painted churches. What makes the restorations of this period different from previous ones, is the fact that now they 
are not limited to the roof but extent to the rest of the monument. Typical examples are St. Antonios in Spilia, St. Epiphanios in Doros, St. John the Forerunner in Mesa Potamos, etc. St. John the Forerunner (Figs. 12(a) and (b)), is a typical single-aisled pitched timber-roof church with a narthex and a semicircular apse at the east. The church is constructed with local stones.

In the other types of Byzantine monuments, the practice for reconstruction tends to be eliminated in the early 1990s. Before that, a characteristic complete reconstruction of a monument that should be mentioned is St. George Chortakiotis in Sotira (Figs. 13(a) and (b)). This church belongs to the cross in square type with a dome and a narthex also of the same type. Both the original building and the narthex are built using well dressed stones. From the 1990s and onwards, there is a tendency for the much ruined churches to be left in the condition of ruins, such as in the case of Arxaggelos in Kellaki, a once singleaisled vaulted church made out of local stones now preserved in ruins (Fig. 14) or in some cases to proceed with the reconstruction of only some of the destroyed parts. Examples of this second tendency are St. Dimitrianos in Akrotiri and St. Stephanos in Pachna.

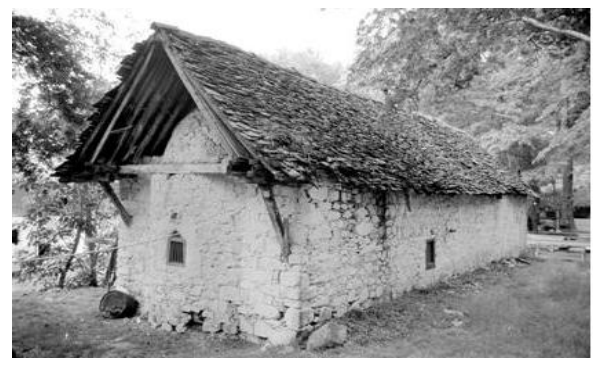

(a)

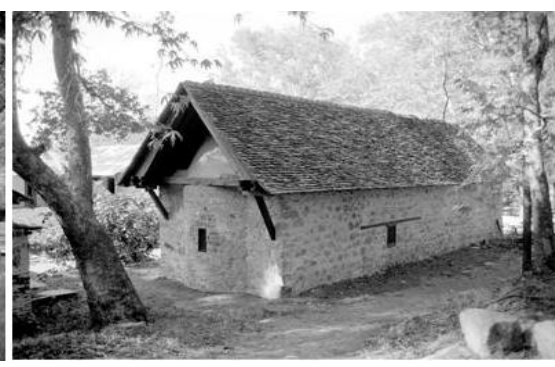

(b)

Figure 12: St. John the Forerunner in Mesa Potamos before and after its complete restoration in 1995 .

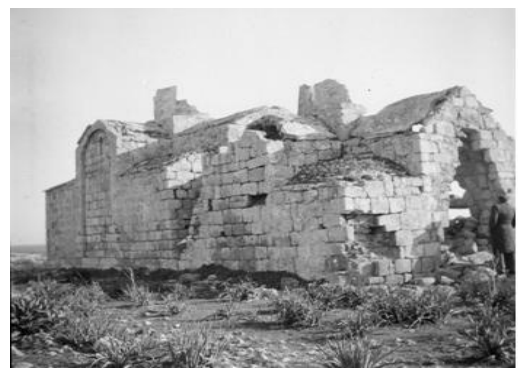

(a)

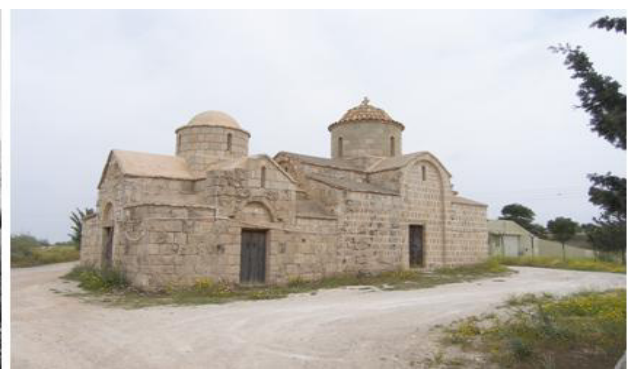

(b)

Figure 13: St. George Chortakiotis in Sotira. The monument before its complete reconstruction in the 1980s and on the right, in its present condition. 


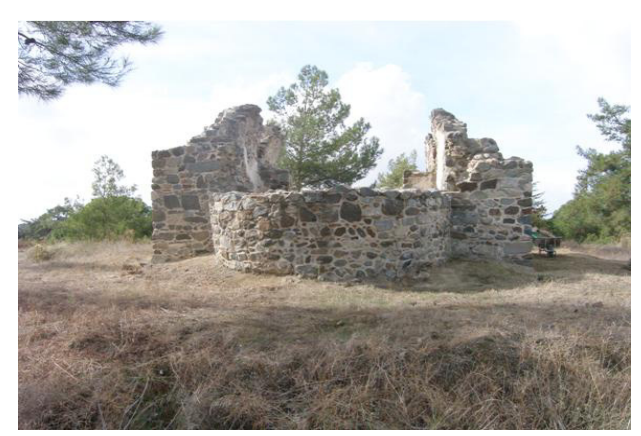

Figure 14: Arxaggelos Michael in Kellaki - preservation in ruins.

The mediaeval monuments that have been restored during this period are very few due to the fact that the majority of them are in the occupied area. Most of these restorations are related with the rehabilitation of the principal mediaeval castles either as district museums (Limassol, Larnaca, Paphos) or local museums (Kolossi, Pyla).

The impact of the Charter of Venice during this period is evident. The Department of Antiquities proceeded during this period, in accordance to Article 1 of the Charter that manifest that monuments are not only considered the examples of monumental architecture, but humble buildings that represent a remote way of living, with the classification of erections of vernacular architecture. From 1980 and onwards, nearly fifty per cent of the restoration works that the Department of Antiquities is contacting annually concerns restorations of buildings of vernacular architecture (houses, watermills, flour mills, wine mills and others).

The restorations of monuments of the recent past were not limited to single monuments. Another impact of the Charter of Venice is the declaration by the Department of Antiquities of areas of special interest. Within this scope, the Department had proceeded in 1978 with the declaration of the rural settlement of Phikardou as a monument and area of special interest, so as to prevent the settlement for complete destruction and abandonment (Fig. 15). Except for the settlement of Phikardou, areas within rural settlements have been declared as areas of special interest in the villages of Pera Oreinis, Lefkara and Kakopetria.

This last period, attention was also given to the drafting of master plans for the better presentation of the various archaeological sites. An important restoration work in an archaeological site was the reconstruction of the southwest corner of the temple of Apollon Hylates at Kourion.

\section{Conclusions}

Cyprus has to show a continuous progress in the field of restorations. One has to look back from the time when the Department of Antiquities was established until today to see how many monuments have been saved from destruction by a 


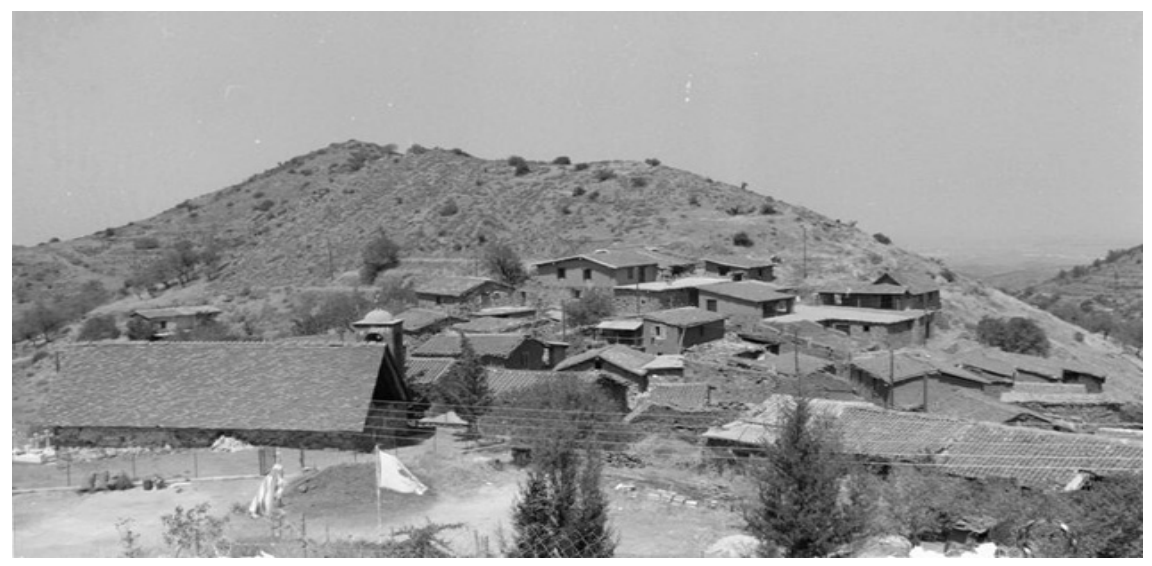

Figure 15: The village of Phikardou after the implementation plan for its revival.

few people and with little money. What needs to be done for obtaining better results in this field is since the personnel of the Department of Antiquities is limited to find a formula that the architects of the private sector could get more involved in the restoration of the monuments of Cyprus. Architecture students should also study the vernacular architecture of the island and need to be taught how to preserve and conserve it.

\section{References}

[1] Karageorghis, V., Des edifices antiques aux monuments chretiens, Le monde de la libre. Archaelogie-Art -Histoire No.112 (Juillet-Aout), pp.24\&27, 1998.

[2] Karadedos, G., History and Theory of Restoration (In Greek), Methexis Publications, Thessaloniki, p.24, 2009.

[3] Enlart, C., Gothic Art and the Renaissance in Cyprus, (translated and edited by David Hunt), Trigraph Editions, London, p. 33, 1987 (first publication 1899).

[4] Kyprianos, Chronological History of the Island of Cyprus (in Greek), (edited by A. Pavlides), Filokypros Publications, p.421, 1977 (first publication in1788).

[5] Theocharides, I.P., Ottoman Scripts 1572-1939. Iera Moni Kykkou Archives, Centre of Iera Moni Kykkou, Nicosia, p.xxxix, 1983.

[6] State Archive/ SA1/3381/1897.

[7] Report of the Department of the Antiquities of Cyprus (RDAC) 1935, p.vii.

[8] Caroe, W.D., The Importance of the Historical Buildings of Cyprus (a lecture), 1931.

[9] Karadedos, G., History and Theory of Restoration (In Greek), Methexis Publications, Thessaloniki, p.96, 2009. 
[10] Brown, G.B., The Care of Ancient Monuments. An account of the legislative and other measures adopted in European countries for protecting ancient monuments and objects and scenes of natural beauty, and for preserving the aspect of historical cities, Cambridge University Press, Cambridge, p.48, 1905.

[11] Musso, M.C., Rapport au sujet de la cathedrale Sainte Sophie aujourd'hui Selimye Mosque, Nicosie, Chypre, Nicosia, 1971. 